\title{
Penerapan Metode Weighted Product Untuk Pemilihan Lokasi Lahan Baru Pemakaman Muslim Dengan Visualisasi Google Maps
}

\author{
Heliza Rahamania Hatta1,*, Muhammad Rizaldi², Dyna Marisa Khairina \\ 1,2,3 Universitas Mulawarman \\ heliza_rahmania@yahoo.com¹, aldiriz13@gmail.com², dyna.ilkom@gmail.com³
}

\begin{abstract}
Difficulty to find space for graveyard for Muslim causes the old cemetery getting crowded. The determination of the land suitability is very crucial for involved decision makers in this case the Regional Government. If not done properly and presicely, an error in land allocation will often cause various problems. Decision Support System can be used to help people to make decisions. Weighted Product Method is a very effective method because the required time for the calculation is much shorter. The purpose of this research is to make the electoral system of prospective new cemetery land for Muslim in Samarinda. It is hoped the system can help the Department of Hygiene and gardening of Samarinda in the process of determining the location of a new cemetery land in Samarinda. Has produced a new system of cemetry land site selection for Muslims using the Weighted Product is supported with visualization google maps. Google maps with visualization make it easier for users to find out information on the location of prospective new cemetry land.
\end{abstract}

Keywords : Decision Support Systems, Weighted Product Methods, Google Maps, Land Cemetery.

Kesulitan lahan pemakaman bagi warga muslim menyebabkan pemakaman lama semakin padat. Penentuan kesesuaian lahan merupakan hal yang sangat krusial bagi para pengambil keputusan yang terkait dalam hal ini Pemerintah Daerah. Jika tidak dilakukan dan secara tepat, alokasi lahan yang keliru seringkali akan mengakibatkan berbagai permasalahan. Sistem Pendukung Keputusan dapat digunakan untuk membantu manusia mengambil keputusan. Metode Weighted Product adalah metode yang sangat efektif karena waktu yang dibutuhkan untuk perhitungan jauh lebih singkat. Tujuan penelitian ini adalah membuat sistem pemilihan lokasi calon lahan baru pemakaman muslim di Samarinda. Diharapkan system dapat membantu Dinas Kebersihan dan Pertamanan Kota Samarinda dalam proses penentuan lokasi lahan pemakaman baru di Samarinda. Telah dihasilkan sebuah sistem pemilihan lokasi lahan baru pemakaman muslimin dengan menggunakan metode Weighted Product yang didukung dengan visualisasi google maps. Dengan visualisasi google maps ini dapat memudahkan pengguna untuk mengetahui informasi letak lokasi calon lahan baru pemakaman

Kata Kunci ; Seistem Pendukung Keputusan, Metode Weighted Product, Google Maps, Lahan Pemakaman.

\section{Pendahuluan}

Bertambahnya jumlah penduduk yang semakin meningkat menyebabkan munculnya kebutuhan ruang terbuka, sedangkan di sisi lain terdapat kebutuhan akan lahan pemakaman [1]. Berdasarkan Standar Negara Indonesia 03-17332004 tentang perencanaan perumahan kota, setiap unit kecamatan kawasan berpenduduk 120.000 jiwa, harus memiliki sekurang-kurangnya 1 (satu) ruang terbuka yang berfungsi sebagai kuburan/pemakaman umum [2].

Di Indonesia, tempat pemakaman diatur oleh Pemerintah Negara Republik Indonesia di bawah Departemen Dalam Negeri yang diatur berdasarkan Peraturan Pemerintah Nomor 9 Tahun 1987 tentang Penyediaan dan Penggunaan Tanah Untuk Keperluan Tempat Pemakaman dan Keputusan Menteri Dalam Negeri Nomor 26 Tahun 1989 tentang Pedoman Pelaksanaan peraturan Pemerintah Nomor 9 Tahun 1987, yang penyelenggaraannya dapat dikelola oleh pemerintah untuk tempat Pemakaman Umum, dan Tempat Pemakaman Bukan Umum pengelolaannya dapat dilakukan masyarakat maupun swasta.

Semakin sulitnya Iahan pemakaman bagi warga menyebabkan pemakaman lama semakin padat yang pada akhirnya masyarakat antar rukun kematian atau antar kelurahan mengusulkan untuk membuat lahan pemakaman baru. Setelah disepakati kemudian calon lahan nantinya diajukan ke Dinas Kebersihan dan Pertamanan Kota Samarinda yang nantinya akan menjadi kebijakan Dinas Kebersihan dan Pertamanan agar dibuat sebagai bahan pertimbangan calon lahan pemakaman. 
Penentuan kesesuaian lahan merupakan hal yang sangat krusial bagi para pengambil keputusan yang terkait dengan hal ini Pemerintah Daerah. Jika tidak dilakukan secara semestinya dan secara benar, alokasi lahan yang keliru seringkaliakan mengakibatkan berbagai permasalahan, baik ekonomi, sosial, budaya, kesehatan, transportasi, keamanan, maupun permasalahan-permasalahan lainnya [3].

Untuk menangani persoalan tersebut digunakanlah metode sistem pendukung keputusan karena pemanfaatan sistem pendukung keputusan dapat digunakan untuk membantu manusia mengambil keputusan dengan cepat, tepat dan konsisten [4].

Banyak metode yang dapat digunakan dalam mengembangkan sistem pendukung keputusan. dan Salah satunya adalah metode Weighted Product. Metode Weighted Product ini lebih efisien karena waktu yang dibutuhkan dalam perhitungan lebih singkat. Metode ini dipilih karena dapat menentukan nilai bobot untuk setiap atribut, kemudian dilanjutkan dengan proses perangkingan yang akan menghasilkan pilihan lokasi lahan pemakaman yang sesuai dengan kriteria [5].

Berdasarkan uraian di atas maka diperlukan sebuah sistem yang dapat menghasilkan model analisis keputusan di dalam menentukan kebijakan pengelolaan lahan, sehingga dapat mereduksi permasalahan lahan di wilayah perkotaan, khususnya dalam penentuan lokasi lahan baru pemakaman di Samarinda, dan untuk mendukung uraian penulis di atas maka penulis mengembangkan sebuah sistem Penerapan Metode Weighted Product dalam Pemilihan Lokasi Lahan Baru Pemakaman Muslim dengan Visualisasi Google Maps yang dapat memberikan rekomendasi lahan sebagai bahan pertimbangan untuk pengambilan keputusan. Pemetaan Google Maps dimanfaatkan untuk menunjukkan titik-titik lokasi rekomendasi lahan yang dihasilkan sistem.

\section{TINJAUAN PUSTAKA}

\section{A. Sistem Pendukung Keputusan}

Sistem Pendukung Keputusan (SPK) merupakan suatu penerapan sistem informasi yang ditujukan untuk membantu pimpinan dalam proses pengambilan keputusan. Sistem pendukung keputusan menggabungkan kemampuan komputer dalam pelayanan interaktif dengan pengolahan atau pemanipulasi data yang memanfaatkan model atau aturan penyelesaian yang tidak terstruktur. Sistem Pendukung Keputusan dimaksudkan menjadi alat bantu bagi para pengambil keputusan untuk memperluas kapabilitas mereka, namun tidak untuk menggantikan penilaian mereka [6].

\section{B. Pemakaman}

Tempat permakaman umum adalah areal tanah yang disediakan untuk memfasilitasi keperluan pemakaman jenazah bagi setiap orang tanpa membedakan agama dan golongan, yang pengelolaannya dilakukan oleh pemerintah kota/kabupaten. Pemerintah kota/kabupaten harus memenuhi kebutuhan penguburan jenazah wilayah yang diperintah.

Berdasarkan standar yang telah ditetapkan oleh SNI 03-1733-2004 tentang Perencanaan Perumahan Kota, setiap kawasan berpenduduk 120.000 jiwa harus memiliki sekurang- kurangnya 1 (satu) ruang terbuka yang berfungsi sebagai kuburan/permakaman umum dengan luas yang tidak ditentukan [7].

\section{Metode Weighted Product}

Metode Weighted Product(WP) menggunakan perkalian untuk menghubungkan rating atribut, dimana rating setiap atribut harus dipangkatkan dulu dengan bobot atribut yang bersangkutan. Proses tersebut sama halnya dengan normalisasi.

Metode Weighted Product dapat membantu dalam mengambil keputusan akan tetapi perhitungan dengan menggunakan metode weighted product ini hanya menghasilkan nilai terbesar yang akan terpilih sebagai alternatif yang terbaik. Perhitungan akan sesuai dengan metode ini apabila alternatif yang terpilih memenuhi kriteria yang telah ditentukan.

Metode weighted product ini lebih efisien karena waktu yang dibutuhkan dalam perhitungan lebih singkat [5]. Preferensi untuk alternatif Ai diberikan sebagai berikut [5] :

$$
S_{i}=\prod_{j=1}^{n} x_{i j} w^{j}
$$

Dengan $\mathrm{i}=1,2, \ldots, \mathrm{m}$; dimana $\Sigma \mathrm{Wj}=1$. Wj adalah pangkat bernilai posistif untuk atribut keuntungan dan bernilai negatif untuk atribut biaya.

$$
W_{j}=\frac{W_{j}}{\Sigma W_{\mathrm{j}}}
$$

Preferensi relatif dari setiap alternatif, diberikan sebagai :

$$
V i=\frac{\prod_{j=1}^{n} X_{i j} w j}{\prod_{j=1}^{n}\left(x_{j}\right) W_{j}} \text { dengan } \mathrm{i}=1,2, \ldots . \mathrm{M}
$$


Sedangkan untuk kriterianya terbagi dalam dua kategori yaitu untuk bernilai positif termasuk dalam kriteria keuntungan dan yang bernilai negatif termasuk dalam kriteria biaya. Definisi dari (3) dimana A merupakan Alternatif, $\mathrm{C}$ merupakan Kriteria, W merupakan Bobot, S merupakan Preferensi untuk alternatif, V merupakan Nilai vektor yang digunakan untuk perankingan, dan $\mathrm{X}$ merupakan Nilai Alternatif dari setiap kriteria [5].

\section{Metodologi Penelitian}

\section{A. Metode Pengumpulan Data}

1) Studi Literatur: Penulis melakukan studi literatur dengan mencari referensi yang berhubungan dengan Sistem Pendukung Keputusan (SPK), Personal Home Page (PHP), My Structured Query Language (MySQL), buku, teks, jurnal dan karya ilmiah sebagai bahan tinjauan pustaka sebagai penunjang penelitian agar tidak menyimpang dari kondisi yang ada.

2) Observasi Lapangan : Penulis melakukan observasi lapangan untuk mengumpulkan data-data yang diperlukan di beberapa tempat berdasarkan rekomendasi Abdul Hasyim Putra, S.P Kepala Seksi Pertamananan Dinas Kebersihan dan Pertamanan Kota Samarinda untuk survei lokasi lahan pemakaman baru dan mengambil titik koordinat dari calon lokasi lahan pemakaman.

3) Wawancara : Penulis melakukan wawancara langsung kepada Bapak Abdul Hasyim Putra, S.P selaku Kepala Seksi Pertamanan Dinas Kebersihan dan Pertamanan Kota Samarinda.

\section{B. Tahap Analisis}

Penulis melakukan anilisis data di mulai dari proses input data calon lahan pemakaman berupa informasi data lahan berupa kriteria beserta data kordinat titik lokasi lahan pemakaman berdasarkan data observasi lapangan ditempat lokasi yang kemudian dilanjutkan dengan proses penerapan sistem pendukung keputusan menggunakan metode weighted product dan menghasilkan output berupa hasil keputusan alternatif calon lahan pemakaman terbaik. Beserta informasi peta visualisasi google maps berdasarkan data lahan yang telah diinputkan sebelumnya.

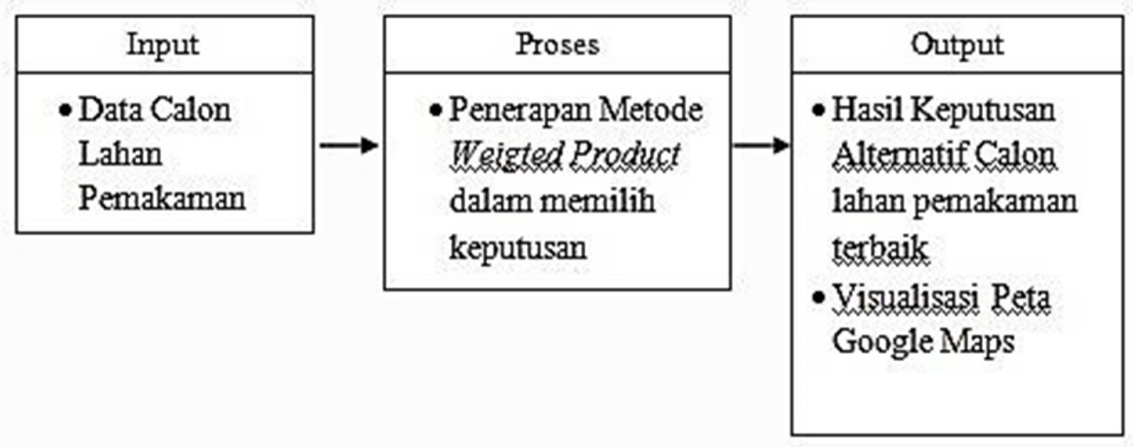

Gambar. 1 Tahap Analisis Sistem

\section{Pemodelan Metode Weighted Product}

Pemodelan metode weighted product dapat dilihat pada Gambar. 2. Langkah awal dengan menginputkan data calon pemakaman berupa kriteria beserta data kordinat titik lokasi lahan pemakaman kemudian data kriteria dikonversikan menjadi data nilai rating kecocokan setelah didapat nilai rating kecocokaan, dilanjutkan dengan proses perhitungan metode Weighted Product. Lalu dilakukan perbaikan bobot dari nilai kriteria, lalu mencari nilai dari preferensi setiap alternatif untuk mendapatkan nilai Vector S, dilanjutkan dengan mencari nilai Vector V. Proses terakhir yaitu memilih alternatif yang memiliki hasil perhitungan dengan nilai tertinggi dan informasi peta visualisasi google maps berdasarkan data kordinat lahan yang telah diinputkan sebelumnya. 


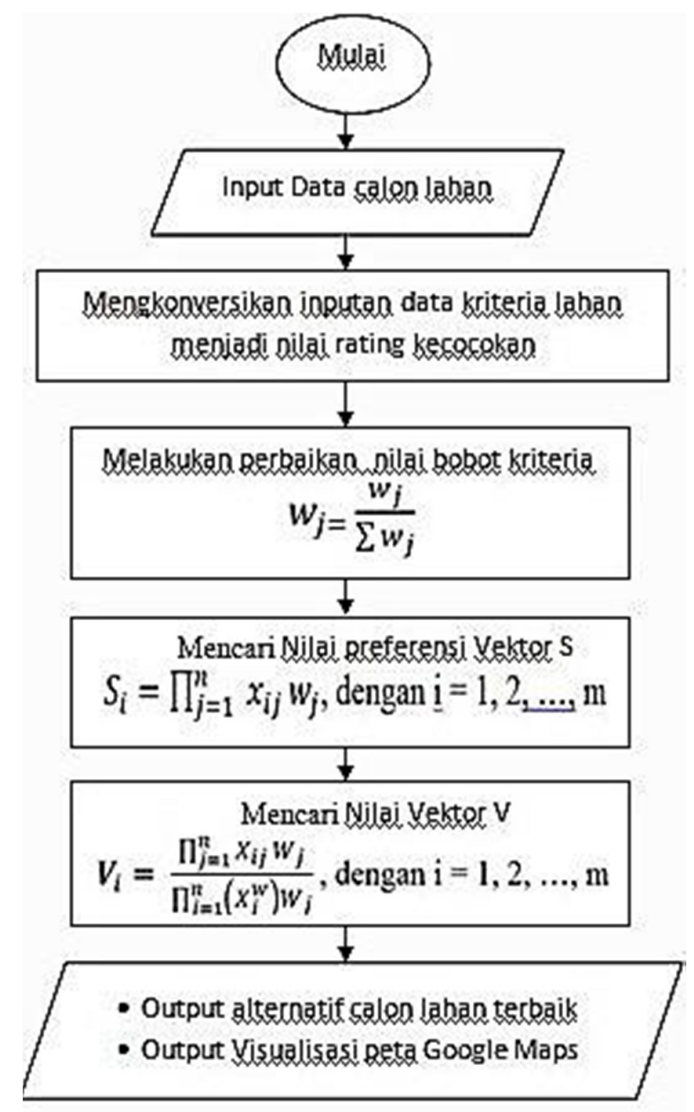

Gambar. 2 Pemodelan Metode Weighted Product

IV. HASIL DAN PEMBAHASAN

\section{A. Pemodelan Sistem}

Sistem Penerapan Metode Weighted Product untuk Pemilihan Lokasi Lahan Baru Pemakaman Muslim dengan Visualisasi Google Maps memiliki empat tahapan proses untuk mendapatkan hasil rekomendasi terbaik lahan pemakaman. Tahapan pertama admin mengisikan data calon pemakaman, berupa informasi titik kordinat lahan pemakaman, informasi empat data kriteria berupa status lahan, luas lahan, jumlah kepadatan penduduk dan jarak dari pemukiman serta informasi lainya. Kemudian sistem akan melakukan proses mengubah inputan data kriteria lahan berupa status lahan, luas lahan, jumlah kepadatan penduduk dan jarak dari pemukiman menjadi data nilai rating kecocokan.

Tahap kedua proses penerapan metode weighted product yaitu perbaikan bobot, dengan cara data nilai bobot status, luas, jumlah kepadatan penduduk dan jarak dari pemukiman nilai keseluruhanya dijumlahkan untuk mendapatkan hasil jumlah bobot. Kemudian dilanjutkan bobot awal dari setiap kriteria status, luas, jumlah kepadatan penduduk dan jarak dari pemukiman dari setiap kriteria dibagi dengan hasil jumlah bobot kriteria untuk mendapatkan nilai perbaikan bobot.

Tahap ketiga proses penerapan metode weighted product yaitu mencari nilai vector $S$ dengan cara data setiap alternatif nilai rating kecocokan lahan kelurahan dikali dan dipangkat dengan hasil nilai perbaikan bobot kriteria

Tahap keempat proses penerapan metode weighted product adalah mencari nilai vector $V$ dengan cara yaitu nilai akhir setiap preferensi vector $S$ dijumlahkan untuk mendapatkan hasil jumlah, setelah di dapatkan hasil jumlah kemudian dilanjutkan dengan setiap preferensi alternatif hasil vector $\mathbf{S}$ dibagi hasill jumlah vector $\mathrm{S}$ untuk mendapatkan nilai vector $\mathrm{V}$ dari setiap alternatif.

Tahap kelima sistem akan melakukan perankingan nilai vector $\mathrm{V}$ tertinggi dari setiap alternatif lahan yang telah diproses menggunakan metode weighted product untuk mendapakan rekomendasi lahan terbaik.

Data nama-nama calon lokasi pemakaman di Samarinda yang ada pada sistem dapat dilihat pada Tabel 1. 
Tabel 1. Data calon lokasi pemakaman di samarinda

\begin{tabular}{|c|l|}
\hline No. & Nama Lokasi Pemakaman di Samarinda \\
\hline 1 & Lahan Kelurahan Sidodadi \\
\hline 2 & Lahan Kelurahan Sungai Pinang Dalam \\
\hline 3 & Lahan Kelurahan Sempaja Utara \\
\hline 4 & Lahan Kelurahan Loa Bahu \\
\hline 5 & Lahan Kelurahan Tanah Merah \\
\hline
\end{tabular}

\section{B. Analisis Data Calon Lokasi Pemakaman}

Data nilai kriteria dan bobot kriteria calon lokasi pemakaman didapatkan dari hasil wawancara terhadap responden Kepala Seksi Pertamanan di Dinas Kebersihan dan Pertamanan Kota Samarinda.

1) Status lahan : Lahan pemerintah adalah yang terbaik. Lahan pemerintah yang dibangun sebagai calon lokasi pemakaman disebut sebagai calon lokasi pemakaman yang pengelolaannya dilakukan oleh pemerintah daerah dalam hal ini Pemerintah Kota Samarinda melalui Satuan Kerja Perangkat Daerah (SKPD) Dinas Kebersihan dan Pertamanan (DKP).

TABEL 2. SKALA PENILAIAN STATUS LAHAN

\begin{tabular}{|l|c|}
\hline \multicolumn{1}{|c|}{ Lahan } & Nilai Bobot \\
\hline Lahan Peorangan & 1 \\
\hline Lahan Wakaf & 2 \\
\hline Lahan Pemerintah & 3 \\
\hline
\end{tabular}

2) Luas lahan: Luas lahan dengan ukuran terluas adalah yang terbaik. Luas lahan calon lokasi pemakaman di wilayah padat penduduk menyesuaikan lahan yang tersedia. Luas lahan dalam hal ini menggunakan hektar (ha).

\begin{tabular}{|c|c|c|}
\hline Luas & Nilai & $\begin{array}{c}\text { Nilai } \\
\text { Bobot }\end{array}$ \\
\hline Luas lahan sangat sempit & 0,02 ha $-0,7$ ha & 1 \\
\hline Luas lahan sempit & 0,8 ha $-1,5$ ha & 2 \\
\hline Luas lahan sedang & 1,6 ha $-2,3$ ha & 3 \\
\hline Luas lahan luas & 2,4 ha $-3,1$ ha & 4 \\
\hline Luas Lahan sangat Luas & 3,2 ha $-3,9$ ha & 5 \\
\hline
\end{tabular}

3) Jumlah kepadatan penduduk: Jumlah penduduk di sekitar lokasi dengan jumlah penduduk yang paling banyak adalah yang terbaik.

TABEL 4. SKALA PENILAIAN JUMLAH KEPADATAN PENDUDUK

\begin{tabular}{|l|c|c|}
\hline \multicolumn{1}{|c|}{ Kepadatan Penduduk } & Nilai & Nilai Bobot \\
\hline Jumlah penduduk sangat sedikit & 10.000 Jiwa - 35.000 Jiwa & 1 \\
\hline Jumlah penduduk sedikit & 35.001 Jiwa - 70.000 Jiwa & 2 \\
\hline Jumlah penduduk sedang & 70.001 Jiwa - 105.000 Jiwa & 3 \\
\hline Jumlah penduduk banyak & 105.001 Jiwa -140.000 Jiwa & 4 \\
\hline Jumlah penduduk sangat banyak & 140.001 Jiwa -175.000 Jiwa & 5 \\
\hline
\end{tabular}


4) Jarak dari pemukiman penduduk: Jarak ke pemukiman penduduk yang terdekat adalah yang terbaik. Berikut ini tabel jarak lahan dengan pemukiman.

\begin{tabular}{|l|c|c|}
\hline \multicolumn{1}{|c|}{ TABEL 5. SKaLA PENILAIAN JARAK DARI PEMUKIMAN } \\
\hline Sangailai & $\begin{array}{c}\text { Nilai } \\
\text { Bobot }\end{array}$ \\
\hline Jauh & 751 Meter - 1.000 Meter & 1 \\
\hline Sedang & 501 Meter - 750 Meter & 2 \\
\hline Dekat & 251 Meter - 500 Meter & 3 \\
\hline Sangat Dekat & 101 Meter - 250 Meter & 4 \\
\hline
\end{tabular}

Dari 4 kriteria diatas diberi skala prioritas 1 - 4. Prioritas 1 menjadi yang terbaik dan seterusnya. Untuk prioritas 1 diberi bobot 4, prioritas 2 diberi bobot 3, prioritas 3 diberi bobot 2, dan prioritas 4 diberi bobot 1. Data dapat dilihat pada Tabel 6.

TABEL 6. BOBOT KRITERIA

\begin{tabular}{|l|c|}
\hline \multicolumn{1}{|c|}{ Nama Kriteria } & Bobot \\
\hline Status kepemilikan lahan & 4 \\
\hline Luas lahan & 3 \\
\hline Kepadatan Penduduk & 1 \\
\hline Jarak dari pemukiman & 2 \\
\hline
\end{tabular}

C. Penerapan Metode Weighted Product di dalam Sistem

Langkah-langkah yang dilakukan dalam menerapkan metode Weighted Product untuk pemilihan alternatif calon lokasi pemakaman terbaik, yaitu:

1. Menentukan kriteria-kriteria yang akan dijadikan acuan dalam pengambilan keputusan.

2. Menentukan input awal dan input akhir untuk merubah nama inputan menjadi nilai rating kecocokan dan menentukan bobot setiap kriteria.

3. Mengubah inputan data calon lokasi pemakaman menjadi nilai rating kecocokan.

4. Melakukan perbaikan bobot dari setiap kriteria dengan cara menjumlahkan bobot setiap kriteria yang dilanjutkan dengan setiap bobot awal kriteria dibagi dengan hasil penjumlahan bobot kriteria

5. Menentukan nilai vektor S alternatif data calon lokasi pemakaman dengan cara mengalikan data nilai rating kecocokan yang berpangkat positif dari hasil perbaikan bobot kriteria

Hasil akhir diperoleh dari proses perangkingan yaitu penjumlahan dari perkalian nilai vektor S dikali dengan setiap alternatif nilai vektor $\mathrm{S}$.

Contoh kasus, lima calon Iokasi pemakaman yaitu Lahan Kelurahan Tanah Merah, Lahan Kelurahan Loa Bahu dan Lahan Kelurahan Sempaja Utara. Data dapat dilihat pada Tabel 7. 
TABEL 7. DATA CALON LOKASI PEMAKAMAN MUSLIM

\begin{tabular}{|l|c|c|c|c|}
\hline \multicolumn{1}{|c|}{ Calon Lahan } & Status & $\begin{array}{c}\text { Luas } \\
\text { (ha) }\end{array}$ & $\begin{array}{c}\text { Jumlah Kepadatan } \\
\text { Penduduk }\end{array}$ & $\begin{array}{c}\text { Jarak dari } \\
\text { pemukiman (m²) }\end{array}$ \\
\hline $\begin{array}{l}\text { Lahan Kelurahan } \\
\text { Tanah Merah }\end{array}$ & Pemerintah & 3 ha & 102.992 jiwa & $100 \mathrm{~m}$ \\
\hline $\begin{array}{l}\text { Lahan Kelurahan Loa } \\
\text { Bahu }\end{array}$ & Wakaf & 2 ha & 130.219 jiwa & $50 \mathrm{~m}$ \\
\hline $\begin{array}{l}\text { Lahan Kelurahan } \\
\text { Sempaja Utara }\end{array}$ & Pemerintah & 0.7 ha & 102.992 jiwa & $105 \mathrm{~m}$ \\
\hline $\begin{array}{l}\text { Lahan Kelurahan } \\
\text { Sungai Pinang Dalam }\end{array}$ & Wakaf & 2,4 ha & 108.937 jiwa & $100 \mathrm{~m}$ \\
\hline $\begin{array}{l}\text { Lahan Kelurahan } \\
\text { Sidodadi }\end{array}$ & Pemerintah & 0,5 ha & 138.836 jiwa & 50 \\
\hline
\end{tabular}

Tahap pertama membuat tabel rating kecocokan untuk alternatif calon lahan yaitu mengubah inputan data calon lahan pemakaman muslim menjadi nilai rating kecocokan. Tabel decision matrix alternatif calon lahan dapat dilihat pada Tabel 8.

\begin{tabular}{|c|c|c|c|c|}
\hline Calon Lahan & Status & Luas (ha) & $\begin{array}{l}\text { Jumlah } \\
\text { Kepadatan } \\
\text { Penduduk }\end{array}$ & $\begin{array}{c}\text { Jarak dari } \\
\text { pemukiman } \\
\left(\mathrm{m}^{2}\right)\end{array}$ \\
\hline $\begin{array}{l}\text { Lahan Kelurahan } \\
\text { Tanah Merah }\end{array}$ & 3 & 4 & 3 & 5 \\
\hline $\begin{array}{l}\text { Lahan Kelurahan } \\
\text { Loa Bahu }\end{array}$ & 2 & 3 & 4 & 5 \\
\hline $\begin{array}{l}\text { Lahan Kelurahan } \\
\text { Sempaja Utara }\end{array}$ & 3 & 1 & 3 & 5 \\
\hline $\begin{array}{l}\text { Lahan Kelurahan } \\
\text { Sungai Pinang } \\
\text { Dalam }\end{array}$ & 2 & 4 & 4 & 4 \\
\hline $\begin{array}{l}\text { Lahan Kelurahan } \\
\text { Sidodadi }\end{array}$ & 3 & 1 & 4 & 5 \\
\hline
\end{tabular}

Tahap kedua yaitu melakukan perbaikan bobot dari setiap kriteria, penjabaran dapat dilihat pada Tabel 9.

\begin{tabular}{|l|c|}
\hline \multicolumn{1}{|c|}{ TABEL 9. PERBAIKAN BOBOT KRITERIA } \\
\hline \multicolumn{1}{|c|}{ Nama Kriteria } & Bobot \\
\hline Status kepemilikan lahan & $4 / 10=0.4$ \\
\hline Luas lahan & $3 / 10=0.3$ \\
\hline Kepadatan Penduduk & $1 / 10=0.1$ \\
\hline Jarak dari pemukiman & $2 / 10=0.2$ \\
\hline
\end{tabular}

Tahap ketiga yaitu menetukan nilai vektor S.

1. Lahan Kelurahan Tanah Merah $S=\left(3^{0.4}\right) \times\left(4^{0.3}\right) \times\left(3^{0.1}\right) \times\left(5^{0.2}\right)=3.624$

2. Lahan Kelurahan Loa Bahu $S=\left(2^{0.4}\right) \times\left(3^{0.3}\right) \times\left(4^{0.1}\right) \times\left(5^{0.2}\right)=2.909$

3. Lahan Kelurahan Sempaja Utara $S=\left(3^{0.4}\right) \times\left(1^{0.3}\right) \times\left(3^{0.1}\right) \times\left(5^{0.2}\right)=2.39$

4. Lahan Kelurahan Sungai Pinang Dalam $S=\left(2^{0.4}\right) \times(40.3) \times(40.1) \times(40.2)=3.035$

5. Lahan Kelurahan Sidodadi $S=\left(3^{0.4}\right) \times(10.3) \times\left(4^{0.1}\right) \times\left(5^{0.2}\right)=2.461$ 
Tahap keempat dilakukan perankingan atau mencari nilai $\mathrm{V}$ dengan cara penjumlahan dari hasil perkalian nilai vektor $\mathrm{S}$ dikali dengan setiap alternatif normalisasi matr nilai vektor $\mathrm{S}$.

1. Lahan Kelurahan Tanah Merah V = (3.624) / $3.624+2.909+2.39+3.035+2.461=0.251$

2. Lahan Kelurahan Loa Bahu V = (2.909) / 3.624 + 2.909+2.39+3.035+ 2.461 = 0.202

3. Lahan Kelurahan Sempaja Utara V $=(2.39) / 3.624+2.909+2.39+3.035+2.461=0.166$

4. Lahan Kelurahan Sungai Pinang Dalam V $=(3.035) / 3.624+2.909+2.39+3.035+2.461=0.21$

5. Lahan Kelurahan Sidodadi $V=(2.461) / 3.624+2.909+2.39+3.035+2.461=0.171$

Dari hasil tersebut dapat disimpulkan bahwa alternatif calon pemakaman muslim terbaik adalah Lahan Kelurahan Tanah Merah dengan $\mathrm{V}=0.251$

D. Implementasi Sistem

Berdasarkan hasil analisis dan perancangan sistem yang telah dilakukan, maka dilakukan implementasi sistem penerapan metode weighted product dalam pemilihan lokasi lahan baru pemakaman muslim dengan visualisasi google maps dengan menggunakan bahasa pemrograman PHP.

E. Halaman Rekomendasi Lahan

Halaman rekomendasi lahan merupakan halaman hasil output data lahan. Dihalaman view maps berfungsi untuk menampilkan visualisasi peta google maps data lahan berdasarkan data lahan yang telah diinputkan sebelumya diproses awal penginputan data lahan. Tampilan halaman view maps dapat dilihat pada Gambar. 3.
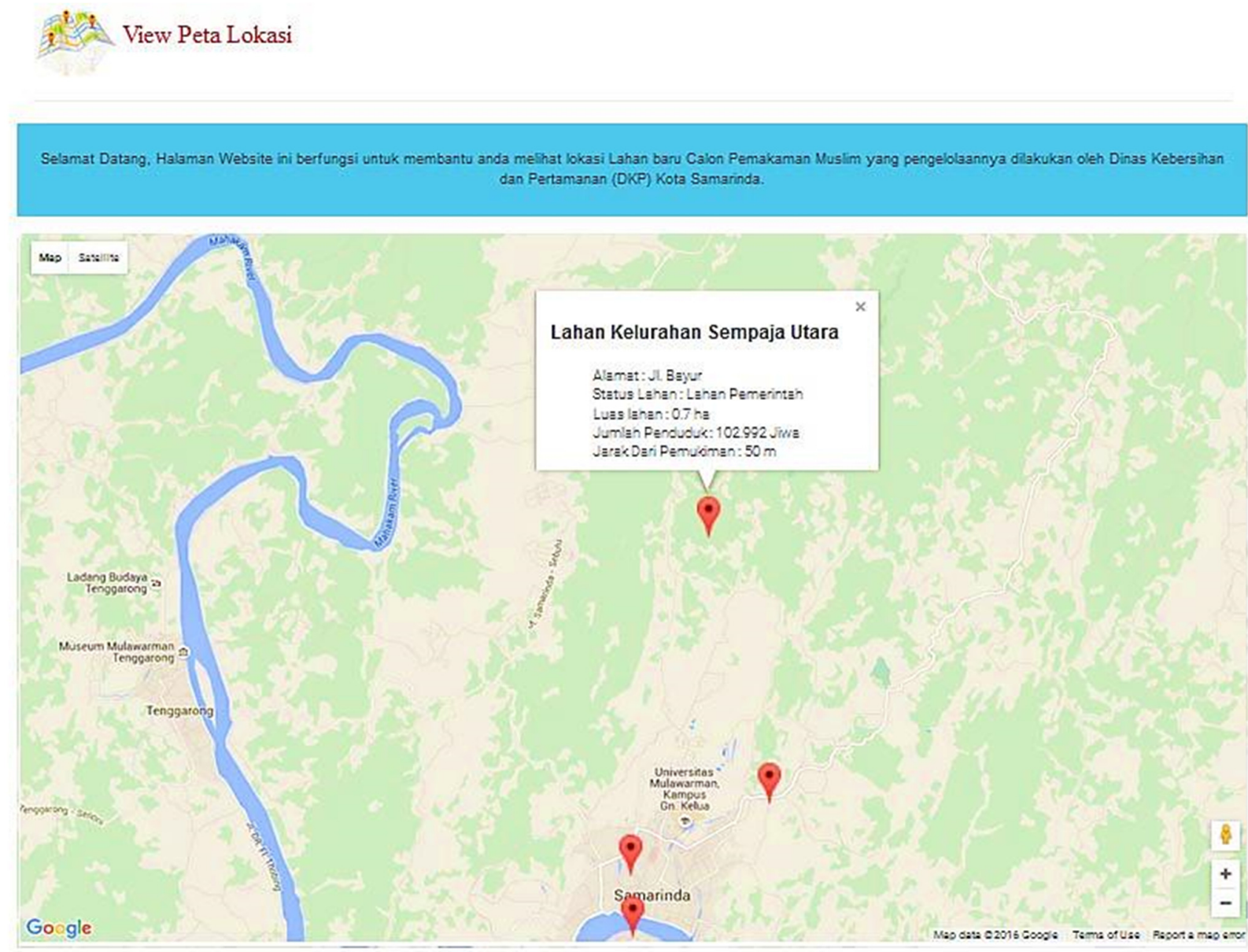

Gambar. 3 Halaman View Maps 
Di halaman perhitungan wp berfungsi untuk menampilkan data perhitungan sistem penunjang keputusan menggunakan metode Weighted Product berdasarkan data yang sebelumnya telah di inputkan dihalaman manajemen calon Iahan. Halaman ini terhubung dengan halaman data calon lokasi makam, halaman kriteria dan halaman bobot inputan kriteria. data yang telah diiputkan dalam database calon makam. yang akan secara otomatis masuk ke halaman perhitungan wp untuk dilakukan pencocokan perhitungan yang disesuaikan dengan data kriteria dan inputan kriteria, dengan tujuan mencari alternatif $\mathrm{V}$ rekomendasi terbaik calon lokasi makam muslim. Tampilan halaman perhitungan wp dapat dilihat pada Gambar. 4.

\section{Perhitungan Metode Weighted Produet}

1

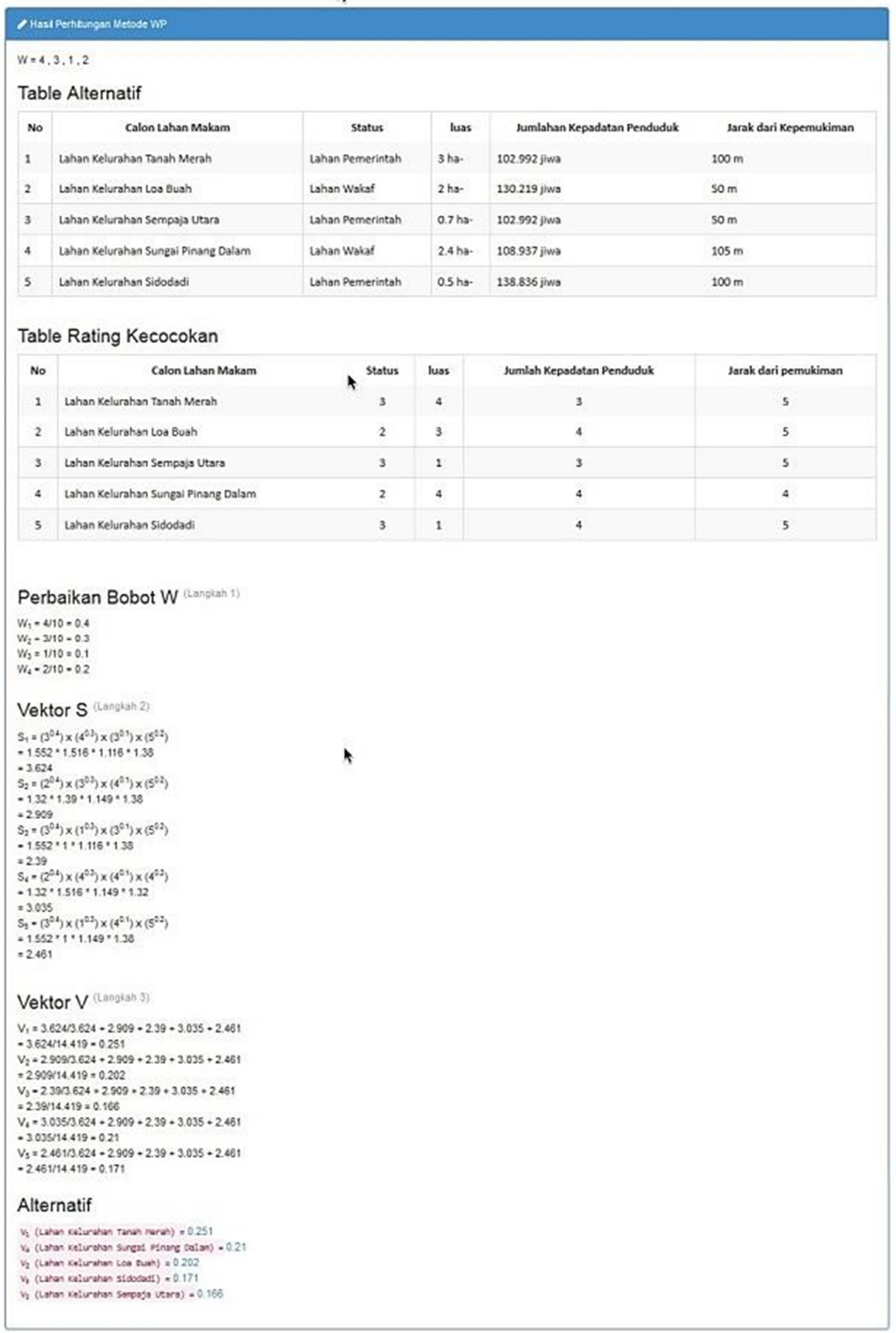

Gambar. 4 Tampilan Halaman Perhitungan WP 
F. Hasil Pengujian Penerapan WP Pada Sistem

Hasil pengujian penerapan metode WP pada sistem sudah sesuai dengan perhitungan secara manual. Perhitungan penunjang keputusan menggunakan metode WP pada sistem menghasilkan alternatif terbaik yaitu calon lokasi pemakaman muslim di bawah lahan kelurahan tanah merah dengan nilai V terbesar yaitu 0.251.

\section{KESIMPULAN DAN SARAN}

A. Kesimpulan

Berdasarkan hasil penelitian mengenai sistem penunjang keputusan untuk pemilihan lokasi pemakaman muslim, dapat diambil kesimpulan :

1. Sistem dapat memberikan rekomendasi pemilihan lokasi calon lahan baru untuk pemakaman muslim di Samarinda sehingga dapat membantu Dinas Kebersihan dan Pertamanan Kota Samarinda dalam proses penentuan lokasi lahan pemakaman baru di Samarinda.

2. Penerapan metode Weighted Product dalam sistem rekomendasi lahan ini memberikan hasil yang efisien karena proses perhitungannya lebih singkat.

3. Sistem ini bekerja berdasarkan kriteria dan bobot yang telah ditentukan oleh pakar kemudian diproses oleh sistem sehingga menghasilkan output perangkingan lahan baru pemakaman muslim.

4. Dengan ditambahkannya visualisasi google maps pada hasil rekomendasi memudahkan pengguna untuk mengetahui informasi letak lokasi calon lahan baru pemakaman.

5. Aplikasi ini diakses melalui browser karena berbasis website, sehingga lebih mudah dan fleksibel karena dapat digunakan dimanapun pengguna berada.

6. Berdasarkan hasil pengujian program, output yang dihasilkan bukan merupakan keputusan akhir. Sistem ini hanya memberikan rekomendasi pemilihan lokasi calon lahan baru pemakaman untuk dijadikan bahan pertimbangan, untuk keputusan akhir tetap berada pada pengguna.

B. Saran

Saran yang dapat diberikan penulis untuk pengembangan sistem ini yaitu:

1. Menambahkan fitur daftar makam yang sudah ada beserta daftar nama orang yang telah dikuburkan di makam tersebut.

2. Menambahkan atau menggunakan metode lain sebagai pembanding dan dapat dijadikan model pengembangan sistem yang lebih baik

\section{REFERENSI}

[1] Wirdanati, C. 2003. ARahan PenataAn Pemakaman Umum Trunojoyo BanyumaniK Dengan Konsep Taman. Universitas Dipenogoro. Semarang.

[2] Badan Standar Negara Indonesia. 2004. Tata Cara Perencanaan Lingkungan Perumahan Di Perkotaan: SNI 03-1733-200

[3] Hartati, Sri, Adi Nugroho. 2012. Sistem Pendukung Keputusan Berbasis AHP (Analytical Hirarcy Process) untuk Penentuan Kesesuaian Penggunaan Lahan (Studi Kasus: Kabupaten Semarang). Jurnal Informatika. Vol 6, No. 2, Juli 2012.

[4] Merdiko, Gery, Septya Maharani, Heliza Rahmania Hatta. 2014. Decision Support System Of Culinary Recommendations Using AHP and TOPSIS Method with Map Visualization. Bisstcch II 2014. Bali.

[5] Sari, Indah Kumala. 2012. Sistem Pendukung Keputusan Penentuan Lokasi Gudang di Perusahaan dengan Metode Weigted Product. Politeknik Caltex. Riau.

[6] Turban, E. 2005. Decision Support System and Inteligent Systems. Jilid1. Edisi 7. Yogyakarta : Penerbit Andi.

[7] Rama, Arianto. 2013. Identifikasi Ketersediaan dan Kebutuhan Tempat Permakaman Umum di Kota Bandung. Institut Teknologi Bandung. Bandung.

[8] Sanjaya, Ary. Dyna Marisa, Septya Maharani, 2015. Rekomendasi Pembelian Grosir Pada Toko Mainan Menggunakan Metode Simple Multi Attribute Rating Technicue (SMART) Dengan Google Maps. Prosiding Seminar Sains dan Teknologi FMIPA Unmul, Samarinda, September 2015, Vol. 1 No.1.

[9] Badan Pusat Statistik. 2015. Samarinda Dalam Angka 2015. Samarinda: Katalog BPS: 1102001.6472

[10] Peraturan Pemerintah Republik Indonesia Nomor 9 Tahun 1987 Tentang Penyediaan Dan Penggunaan Tanah Untuk Keperluan Tempat Pemakaman. 1987 Jakarta. 